\title{
DEACTIVATION OF PERSISTENTLY ACTIVATED PANCREATIC ADENYLATE CYCLASE. EVIDENCE OF UNCOUPLING OF HORMONE RECEPTORS AND ENZYME EFFECTOR IN THE PERSISTENTLY ACTIVATED STATE, AND OF THE PRESENCE OF TWO GUANYL NUCLEOTIDE REGULATORY SITES
}

\author{
M. SVOBODA, P. ROBBERECHT and J. CHRISTOPHE \\ Department of Biochemistry and Nutrition, Medical School of the Université libre de Bruxelles, Boulevard of Waterloo 115 ; \\ B-1000 Brussels, Belgium
}

Received 23 June 1978

\section{Introduction}

Pancreatic acinar cells have distinct binding sites for secretin and pancreozymin [1-3]. Each gastrointestinal hormone stimulates a membrane adenylate cyclase system through the activation of a common catalytical unit $[4,5]$. As in other eukaryotic systems [6-10] guanine nucleotides are positive activators of the hormone stimulated enzyme activity [11]. In numerous systems [12-17], when $\mathrm{p}(\mathrm{NH}) \mathrm{ppG}$ (a stable analog of GTP) and a hormone are used in combination, there results a permanent activation of adenylate cyclase, i.e., durable high activity resisting extensive washing or exposure to a hormone antagonist. In turkey erythrocyte plasma membranes permanently activated by 1 -epinephrine and $\mathrm{p}(\mathrm{NH}) \mathrm{ppG}$, this state was shown to be reversible provided epinephrine and GTP were added simultaneously [15-17]. The hormone produced two added effects: (a) the release of bound p(NH)ppG [16], and (b) the activation of a membrane specific GTPase $[18,19]$.

We investigated the mechanism for persistent activation of pancreatic adenylate cyclase and its possible reversibility by deactivation, by taking advantage of the coexistence of two independent hormone receptors capable of interacting with a unique effector subunit. The data are compatible with a model postulating that hormone receptors and the adenylate cyclase effector are not permanently coupled in the active state and that two guanyl nucleotide regulatory sites are involved, one promoting enzymatic activity of the catalytic subunit and another associated with a hormone receptor and acting to transduce the hormonal signal.

\section{Materials and methods}

(a) Natural porcine secretin and the synthetic C-terminal octapeptide of cholecystokinin-pancreozymin (OC-PZ) were generous gifts from, respectively, Dr V. Mutt (Karolinska Institutet, Stockholm, Sweden) and Dr M. Ondetti (Squibb Institute for Medical Research, Princeton, N.J., USA).

$\left[\alpha-{ }^{32} \mathrm{P}\right]$ ATP and cyclic $\left[{ }^{3} \mathrm{H}\right]$ AMP were purchased from The Radiochemical Center (Amersham, Great Britain). Guanosine ( $\beta-\gamma$ imido)triphosphate $(\mathrm{p}(\mathrm{NH}) \mathrm{ppG}$ ) and GTP were obtained from Boehringer (Mannheim, Germany). ATP, phospho(enol)pyruvate, pyruvate kinase and cyclic AMP were obtained from Sigma Chemical Co. (St. Louis, Mo., USA). All other reagents were commercial preparations of analytical grade.

(b) Rat pancreatic plasma membranes were prepared as previously described [5] and stored in liquid nitrogen until use.

(c) Adenylate cyclase assay: Membranes (2-10 $\mu \mathrm{g}$ protein) were incubated for $10 \mathrm{~min}$ at $37^{\circ} \mathrm{C}$ in a final volume of $0.06 \mathrm{ml}$ in a medium previously detailed [11]. Cyclic AMP was extracted by sequential chromatographies [20]. The enzyme activity observed in the presence of $30 \mu \mathrm{M}$ p(NH)ppG with $0.3 \mu \mathrm{M}$ 
OC-PZ and/or $0.3 \mu \mathrm{M}$ secretin was that allowing maximal activity [11],

(d) Persistent activation of pancreatic adenylate cyclase: 1-2 mg membrane protein were incubated at $30^{\circ} \mathrm{C}$ in the combined presence of $30 \mu \mathrm{M} \mathrm{p}(\mathrm{NH}) \mathrm{ppG}$ and of $0.3 \mu \mathrm{M} \mathrm{OC}-\mathrm{PZ}$ or $0.3 \mu \mathrm{M}$ secretin (i.e., saturating concentrations, ref. [11]) in a medium containing $50 \mathrm{mM}$ Tris-HCl buffer ( $\mathrm{pH} 7.4), 5 \mathrm{mM} \mathrm{MgCl}_{2}, 5 \mathrm{mM}$ dithioerythritol, and mixed hepatic phospholipids $(0.2 \mathrm{mg} / \mathrm{ml})$. The final volume was $2.4 \mathrm{ml}$. The incubation was stopped by adding $7 \mathrm{ml}$ of ice-cold washing buffer A composed of $20 \mathrm{mM}$ Hepes-Tris (pH 7.4) with $0.1 \mathrm{mM} \mathrm{MgCl}, 30 \mathrm{mM} \mathrm{NaCl}$, and $0.1 \mathrm{mM}$ dithioerythritol. After immediate centrifugation at $50000 \times \mathrm{g}$ for $5 \mathrm{~min}$ at $0^{\circ} \mathrm{C}$, the pellet was rehomogenized in buffer $\mathrm{A}$ and centrifuged again; this procedure was repeated three times. Washed membranes were finally resuspended in buffer A, sonicated $(3 \times 0.5 \mathrm{~s})$ and assayed for adenylate cyclase activity in the standard medium with or without $30 \mu \mathrm{M} \mathrm{p}(\mathrm{NH}) \mathrm{ppG}$, and with or without the simultaneous presence of $0.3 \mu \mathrm{M} \mathrm{OC}-\mathrm{PZ}$ or $0.3 \mu \mathrm{M}$ secretin. The catalytical activity attainable with $\mathrm{p}(\mathrm{NH}) \mathrm{ppG}$ and hormone together was considered as maximal and the persistent activity observed in these membranes was expressed as percent of this maximal activity.

(e) Deactivation of adenylate cyclase in a persistent active state: Plasma membranes were preactivated as described at the beginning of the previous paragraph but their dispersion was obtained by homogenization in buffer $\mathrm{A}$ rather than by sonication. Dilution and incubation were conducted in buffer $\mathrm{B}$, made of $30 \mathrm{mM}$ Tris- $\mathrm{HCl}$ ( $\mathrm{pH} 7.4$ ), $5 \mathrm{mM} \mathrm{MgCl}, 0.5 \mathrm{mM}$ EGTA, mixed phospholipids $(0.2 \mathrm{mg} / \mathrm{ml}), 10 \mathrm{mM}$ phospho(enol)pyruvate, pyruvate kinase $(30 \mu \mathrm{g} / \mathrm{ml})$, $0.5 \mathrm{mM}$ ATP (to protect GTP from degradation [11]), and without or with $30 \mu \mathrm{M} \mathrm{GTP}$, and/or the hormone tested at saturating concentration. At various time intervals, the membranes were washed three times at $0^{\circ} \mathrm{C}$ by the above mentioned procedure. The washed pellet was sonicated in buffer $A$ to a final membrane protein concentration of $0.1-0.2 \mathrm{mg}$ per $\mathrm{ml}$. The residual persistent adenylate cyclase activity was determined as described in paragraph (d).

(f) Protein determination was performed by the method of Lowry et al. [21].

\section{Results}

Incubation of rat pancreatic plasma membranes with $\mathrm{p}(\mathrm{NH}) \mathrm{ppG}$ alone or in the presence of the nucleotide and OC-PZ or secretin led to a persistent activation of adenylate cyclase, i.e., maximal activity resisting extensive washing by centrifugationresuspension at $0^{\circ} \mathrm{C}$. The rate of persistent activation was hormone-responsive. In the combined presence of saturating concentrations of $\mathrm{p}(\mathrm{NH}) \mathrm{ppG}$ and peptide hormone, a $5 \mathrm{~min}$ incubation at $30^{\circ} \mathrm{C}$ sufficed

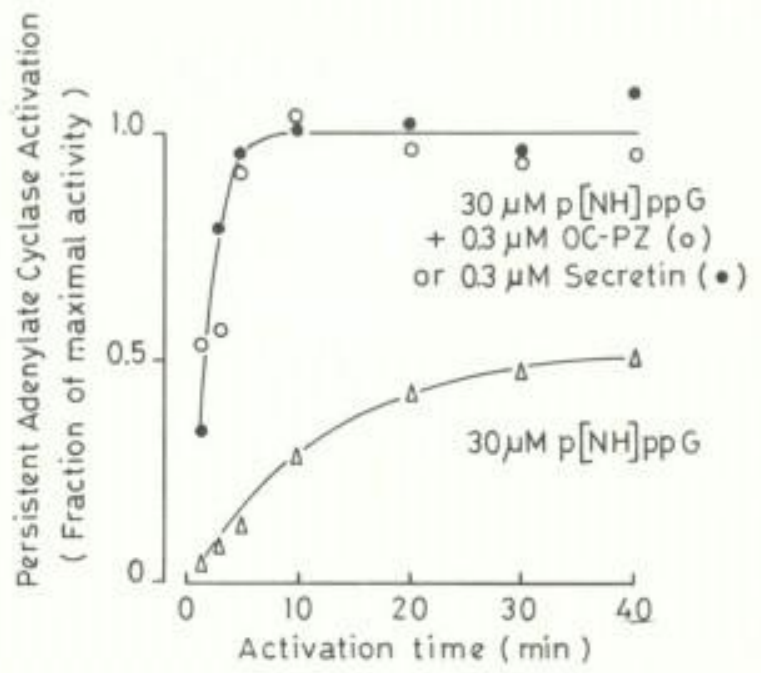

Fig.1. Time study of the persistent activation of pancreatic adenylate cyclase. Pancreatic plasma membranes were incubated at $30^{\circ} \mathrm{C}$ in $2.4 \mathrm{ml}$ of $50 \mathrm{mM}$ Tris-HCl buffer (pH 7.4) containing $5 \mathrm{mM} \mathrm{MgCl}$ and $2 \mathrm{mM}$ dithioerythritol and with $30 \mu \mathrm{M} \mathrm{p}(\mathrm{NH}) \mathrm{ppG}$ alone $(\Delta-\Delta-\Delta)$ or in the presence

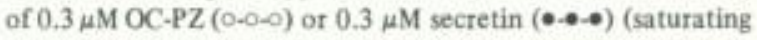
concentrations, ref. [11]). At indicated times, $0.3 \mathrm{ml}$ aliquots were removed, diluted with $6 \mathrm{ml}$ of cold washing buffer $\mathrm{A}$ and stored at $0^{\circ} \mathrm{C}$ until the end of the time study. The membranes were then washed as indicated in the experimental section, and finally sonicated $(3 \times 0.5 \mathrm{~s})$ in $0.15 \mathrm{ml}$ of washing buffer A. Aliquots of $0.02 \mathrm{ml}$ were assayed in triplicate for adenylate cyclase activity under two conditions: in the standard assay medium or in the combined presence of saturating concentrations of $\mathrm{p}(\mathrm{NH}) \mathrm{ppG}(30 \mu \mathrm{M}), \mathrm{OC}-\mathrm{PZ}$ $(0.3 \mu \mathrm{M})$, and secretin $(0.3 \mu \mathrm{M})$. The value attained with the activators $\left(0.66 \pm 0.04\right.$ nmoles of cyclic AMP $\cdot$ min $^{-1} \cdot m g$ prot $^{-1}$ ) was considered as the maximal level of adenylate cyclase activity. Activities observed in the simple standard assay medium were considered as representing the persistent activation attained during the time study and were expressed as a fraction of maximal activation. Each time study was a separate experiment. 
to achieve full persistent activation whereas the activation was much slower with the nucleotide alone, a 30 min incubation allowing only half-maximal persistent activity (fig.1).

The persistently active state was reversible provided OC.PZ and GTP (or ATP) were added together (fig.2). Kinetic data show that in the presence of OC.PZ and GTP, $50 \%$ of the permanent activity was lost during
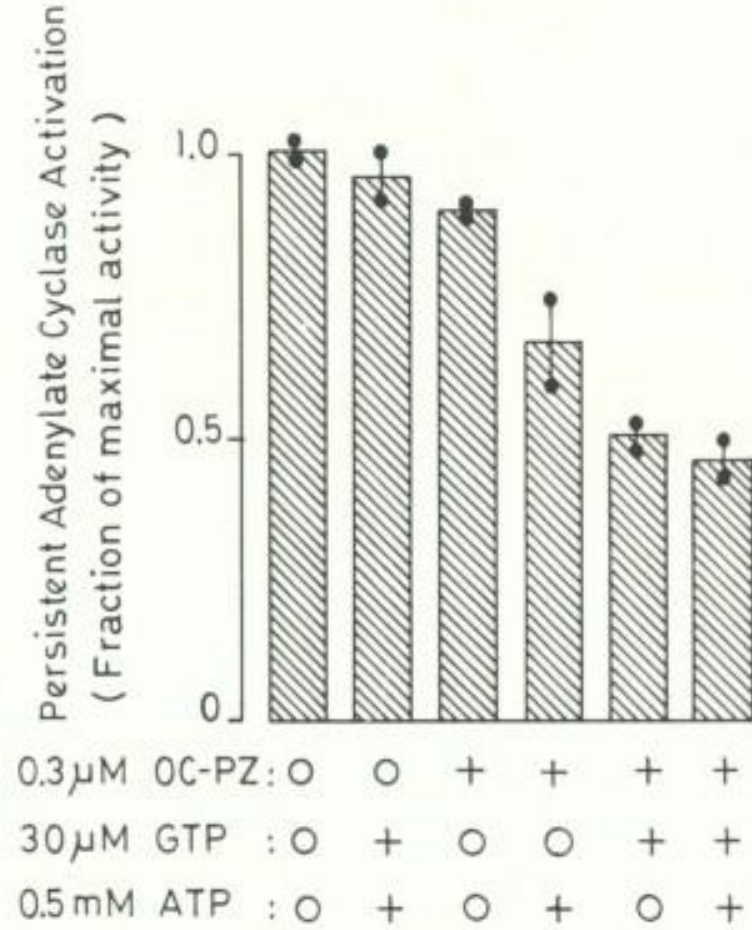

Fig.2. Conditions required for the reversible deactivation of persistently activated adenylate cyclase. Pancreatic plasma membranes were fully activated by a $10 \mathrm{~min}$ preexposure to $30 \mu \mathrm{M}$ p(NH)ppG and $0.3 \mu \mathrm{M} \mathrm{OC}-\mathrm{PZ}$ as described under section 2 . After 3 washings, they were resuspended and then incubated for $10 \mathrm{~min}$ at $37^{\circ} \mathrm{C}$ in a final volume of $0.3 \mathrm{ml}$ of ATP-free buffer B in the presence $(+)$ or absence $(0)$ of $0.5 \mathrm{mM} \mathrm{ATP}, 30 \mu \mathrm{M}$ GTP and $0.3 \mu \mathrm{M} \mathrm{OC-PZ}$. The membranes were then washed three times and sonicated in $0.2 \mathrm{ml}$ of buffer A. Adenylate cyclase activities were assayed in triplicate in $0.02 \mathrm{ml}$ aliquots under control conditions or in the combined presence of $30 \mu \mathrm{M} \mathrm{p}(\mathrm{NH}) \mathrm{ppG}$, $0.3 \mu \mathrm{M} \mathrm{OC} \cdot \mathrm{PZ}$, and $0.3 \mu \mathrm{M}$ secretin. The value attained with activators represented maximal adenylate cyclase stimulation and the activities obtained in the control medium were expressed as a fraction of this maximal stimulation. The two separate experiments were performed with membranes having a maximal adenylate cyclase activity of, respectively, 0.64 and $1.05 \mathrm{nmol}$ of cyclic AMP $\cdot \mathrm{min}^{-1} \cdot \mathrm{mg} \mathrm{prot}^{-1}$. the first 15 min and then followed a slower rate of deactivation (fig.3). Each peptide and nucleotide was ineffective if used alone (fig.2). The deactivation obtained could be reversed by repetition of the activation procedure.

The persistent activation caused by secretin and p $(\mathrm{NH})$ ppG could be reversed by OC-PZ and GTP. Similarly the persistent activation caused by OC.PZ and $p(\mathrm{NH}) \mathrm{ppG}$ could be reversed by secretin in the presence of GTP (table 1). Such deactivation by the reciprocal hormone was somewhat less efficient than that provoked by treatment with the same hormone which had been used in the activation procedure but this might simply reflect the protection of the corresponding receptor afforded by the hormone during the preactivation step.

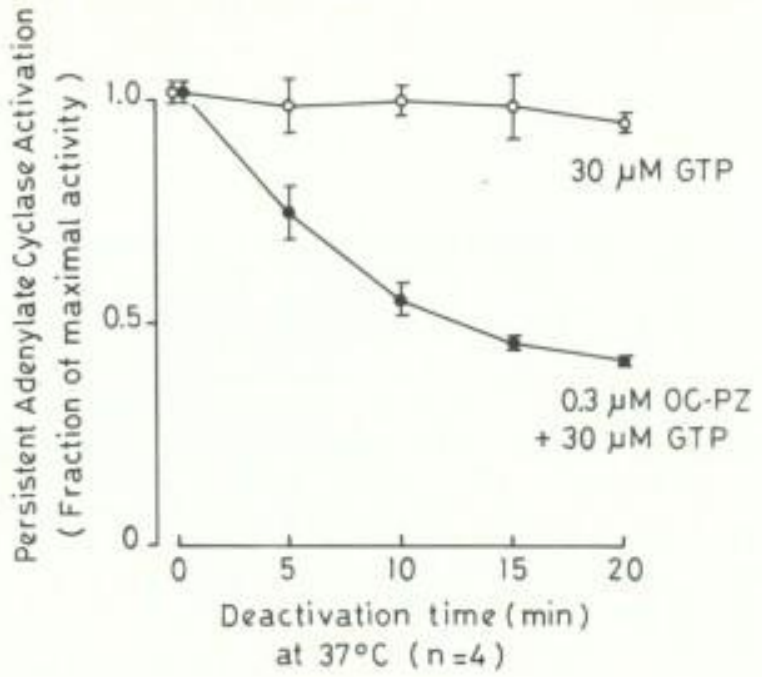

Fig.3. Kinetics of reversal of the persistently active state of pancreatic adenylate cyclase. Membranes were persistently activated by $30 \mu \mathrm{M}$ p(NH)ppG and $0.3 \mu \mathrm{M} \mathrm{OC}-\mathrm{PZ}$ as described under section 2 . After $10 \mathrm{~min}$ of pre-incubation, the membranes were washed three times, homogenized and incubated in $1.2 \mathrm{ml}$ of buffer B enriched with $30 \mu \mathrm{M}$ GTP

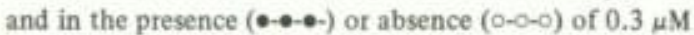
OC-PZ. The extent of deactivation was monitored by removing $0.2 \mathrm{ml}$ aliquots at the indicated times, dilution by $7 \mathrm{ml}$ of cold buffer $\mathrm{A}$ and storage at $0^{\circ} \mathrm{C}$. At the end of the time study, all membrane aliquots were centrifuged and washed three times (see under section 2). Persistent adenylate cyclase stimulation was assayed and expressed as described in fig.2. Means \pm SEM of four separate experiments. The maximal adenylate cyclase activity was $0.68 \pm 0.10 \mathrm{nmol}$ cyclic AMP $\cdot \mathrm{min}^{-1} \cdot \mathrm{mg}^{-1}$. 
Table 1

Cross-deactivation of persistently activated pancreatic adenylate cyclase by OC-PZ and by secretin

\begin{tabular}{llll}
\hline $\begin{array}{l}\text { Number of experiments } \\
\text { Step I: Activation with }\end{array}$ & 4 & 5 & 3 \\
$30 \mu \mathrm{M}$ p(NH)ppG & & & \\
$0.3 \mu \mathrm{M}$ hormone & OC-PZ & + & + \\
\end{tabular}

Step II: \% of maximal activity after a 10 min deactivation with

(a) $30 \mu \mathrm{M}$ GTP

(b) $30 \mu \mathrm{M} \mathrm{GTP}+0.3 \mu \mathrm{M} \mathrm{OC}-\mathrm{PZ}$

(c) $30 \mu \mathrm{M} \mathrm{GTP}+0.3 \mu \mathrm{M}$ secretin

(d) $30 \mu \mathrm{M} \mathrm{GTP}+0.3 \mu \mathrm{M}$ OC-PZ $+0.3 \mu \mathrm{M}$ secretin

$\begin{array}{lll}93 \pm 5 & 70 \pm 4 & 44 \pm 7 \\ (100) & (100) & (100) \\ 48 \pm 7 & 57 \pm 3 & 22 \pm 2 \\ (52) & (81) & (51) \\ 59 \pm 5 & 44 \pm 4 & 32 \pm 3 \\ (63) & (63) & (72) \\ 35 \pm 2 & 44 \pm 5 & 24 \pm 3 \\ (38) & (63) & (54)\end{array}$

Step I: Plasma membranes were persistently activated by either incubation for 10 min at $30^{\circ} \mathrm{C}$ with $30 \mu \mathrm{M} \mathrm{p}(\mathrm{NH}) \mathrm{ppG}$ used in combination with $0.3 \mu \mathrm{M} \mathrm{OC}-\mathrm{PZ}$ or $0.3 \mu \mathrm{M}$ secretin, or for $30 \mathrm{~min}$ at $30^{\circ} \mathrm{C}$ with $30 \mu \mathrm{M}$ p(NH)ppG alone. The membranes were then washed 3 times to remove free and loosely bound activators. Their maximal activity was $0.76=0.08$ nmoles cyclic AMP $\cdot \min ^{-1} \cdot \mathrm{mg}_{\mathrm{grot}}{ }^{-1}$. Step II: These preactivated membranes were incubated in $0.3 \mathrm{mI}$ of buffer B enriched with $30 \mu \mathrm{M}$ GTP and in presence or absence of added hormone(s). After $10 \mathrm{~min}$ at $37^{\circ} \mathrm{C}$, the membranes were washed 3 times and sonicated in $0.2 \mathrm{ml}$ of buffer A. Aliquots of $20 \mu \mathrm{l}$ were assayed for adenylate cyclase activity in the standard medium or in the presence of $30 \mu \mathrm{M}$ p(NH)ppG with $0.3 \mu \mathrm{M} \mathrm{OC}-\mathrm{PZ}$ and $0.3 \mu \mathrm{M}$ secretin. Persistent activation was expressed in percent of maximal adenylate cyclase activity as in fig. 2 . The values in parentheses give the residual persistent activation expressed in percent of the control deactivation procedure, conducted with $30 \mu \mathrm{M}$ GTP only. All values are the mean \pm SEM of 3-5 separate experiments

\section{Discussion}

According to a well documented model $[22,23]$ and to previous observations [11], the activation of rat pancreatic adenylate cyclase by GTP and a hormone begins with the rapid binding of GTP followed by a molecular transition which leads to its activation. The rate constants of this transition can be increased by secretin and OC-PZ. This can be formulated as follows:

$E+\mathrm{GTP} \underset{\vec{k}_{-1}}{\stackrel{k_{1}}{\longrightarrow}} E$.GTP $\underset{k_{-2}}{\stackrel{k_{2}}{\rightleftharpoons}} E * \mathrm{GTP} \stackrel{k_{3}}{\rightarrow} E+\mathrm{GDP}+\mathrm{P}_{\mathrm{i}}$

where $E$ represents the basal form of adenylate cyclase and $E^{*}$ the active form of the enzyme. $E$ is regenerated at a rate determined by $k_{3}$ corresponding to the irreversible hydrolysis of GTP by a GTPase activity associated with $E[18,19]$.

When a non-hydrolyzable analog of GTP $G^{\prime}$ and not GTP is used, the value of $k_{3}$ is nil and the reversibility of the activation can only be achieved by returning to states $E . G^{\prime}$ and $\mathrm{E}$ with the corresponding rate constants $k_{-2}$ and $k_{-1}$, the determining step being the conversion of $E_{*}^{*} G^{\prime}$ into $E . G^{\prime}[11]$. In state $E * G^{\prime}$ the GTP analog is bound and its conformation can modulate the activity of $E^{*}$ : this is why $\mathrm{p}(\mathrm{NH}) \mathrm{ppG}, \mathrm{p}\left(\mathrm{CH}_{2}\right) \mathrm{ppG}$ and $\mathrm{GTP} \gamma \mathrm{S}$ allow distinct app. $V$ values for $E^{*}[24]$ :

$E+G^{\prime} \underset{k_{-1}}{\stackrel{k_{1}}{\rightleftarrows}} E \cdot G^{\prime} \frac{k_{2}}{k_{-2}} E * G^{\prime}-x \rightarrow$ 
The two major conclusions warranted by the pres. ent data on rat pancreatic plasma membranes justify an extension of the preceding model:

(1) The active state $E^{*}$ obtained in the presence of $\mathrm{p}(\mathrm{NH}) \mathrm{ppG}$ and persisting after extensive membrane washing (i.e., after removal of free hormone and nucleotide) could be reversed only when a hormone and GTP were added simultaneously. (We confirmed (fig.2) that ATP at a $0.5 \mathrm{mM}$ concentration could partially mimic the effects of GTP [17].) Since $E^{*}$ required the durable occupation of a regulatory guanyl binding site (see above), the added nucleotide needed for deactivation must bind to another site probably coupled with the hormone receptor. This is further indirect evidence of the existence of two guanyl binding sites in addition to the evidence recently documented in liver plasma membranes [25]. Another argument favoring the existence of a specific guanyl nucleotide site controlling hormone binding in rat pancreatic plasma membranes is the marked increase in the rate of dissociation of $\left[{ }^{3} \mathrm{H}\right]$ caerulein (an analog of OC-PZ) and of [ ${ }^{125}$ I] VIP (a parent hormone of secretin) in the presence of guanyl nucleotides $([3,26]$ and unpublished data). Thus the first guanyl regulatory site appears essential in the permanent activation of $E$ by $\mathrm{p}(\mathrm{NH}) \mathrm{ppG}$ while the second guanyl regulatory site, when occupied, might stimulate the transduction of the hormone-generated signal and also enhance the rate of dissociation of the membrane bound hormone.

(2) In the presence of GTP, the reversibility of the persistently active state of pancreatic adenylate cyclase was achieved by secretin as well as by OC-PZ irrespective of the hormone used to promote activation. From previous studies it is apparent that the hormone receptors and $E$ are not permanently bound in the absence of a hormone $[27-30]$. In pancreatic membranes full and rapid activation required the simultaneous presence of a hormone and of a guanyl nucleotide, suggesting the involvement of an intermediate complex H.R.G.E.G. These results might be explained in either of two ways: (1) a tight constant association of OC-PZ receptors with secretin receptors; this hypothetical clustering of distinct hormone receptors is unlikely since both peptides cannot compete at the level of their binding sites [3] therefore suggesting the spatial independence of their receptors; (2) the uncoupling of the first hormone receptor so that the enzymatic effector can now diffuse in the plane of the cell membrane and interact with another hormone bound receptor during the deactivation process; this model requires the existence of the free $E^{*}$ species. It ressembles the collision coupling mechanism recently developed by Tolkovsky and Levitzki [32] for turkey erythrocyte membranes on the basis of another experimental approach.

To conclude, the following tentative model fits the present results and differs from those in which the hormone bound receptor and the effector remain associated in the active state $[27,28]$ and those in which the only guanyl regulatory site is a GTPase bound to the catalytic subunit:

(a) The process leading to permanent activation in the presence of OC-PZ $\left(H^{1}\right)$ and $\mathrm{p}(\mathrm{NH}) \mathrm{ppG}$ includes the formation of a transient complex $H^{1}{ }^{1} R^{1} E$. requiring the binding of $\mathrm{p}(\mathrm{NH}) \mathrm{ppG}$ to two regulatory sites which are coupled, respectively, with $R^{1}$ and $E$. A molecular transition $\left(k_{2}\right)$ leads to a complex and highly active state in equilibrium with the free active effector species $E^{*}$ holding one p(NH)ppG. The washing of membranes shifts the equilibrium in favor of the free active effector species:

$$
\begin{aligned}
& R^{1}+E \stackrel{+H^{1} ;+G^{\prime}}{\rightleftharpoons} H^{1} \cdot R^{1}\left[G^{\prime}\right] \cdot E\left[G^{\prime}\right] \stackrel{\frac{k_{2}}{\stackrel{k_{-2}}{\rightleftharpoons}}}{ } \\
& H^{1} \cdot R^{1}\left[G^{\prime}\right] \cdot E^{*}\left[G^{\prime}\right] \stackrel{-H^{1} ;-G^{\prime}}{\rightleftharpoons} R^{1}+E^{*}\left[G^{\prime}\right]
\end{aligned}
$$

where $G^{\prime}$ represents $\mathrm{p}(\mathrm{NH}) \mathrm{ppG}$

(b) The deactivation of persistent activation observed when secretin $\left(\mathrm{H}^{2}\right)$ and GTP are offered simultaneously to washed membranes begins with the coupling of $E^{*}$ with $H^{2} R^{2}$. Next p(NH)ppG is exchanged for GTP and deactivation is achieved by the washing of the membranes and the hydrolysis of GTP (thanks to the GTPase activity present in E):

$$
\begin{aligned}
& R^{2}+E^{*}\left[G^{\prime}\right] \stackrel{+H^{2} ;+G}{\rightleftharpoons} H^{2} \cdot R^{2}[G] \cdot E^{*}\left[G^{\prime}\right] \stackrel{k_{-2}^{\prime}}{\frac{k_{2}^{\prime}}{\rightleftharpoons}} \\
& H^{2} \cdot R^{2}[G] E\left[G^{\prime}\right] \stackrel{-G^{\prime} ;+G}{=} H^{2} \cdot R^{2}[G] \cdot E[G] \\
& \stackrel{-H^{2} ;-G D P ;-\mathrm{P}_{\mathrm{j}}}{=} R^{2}+E ;
\end{aligned}
$$


where $G^{\prime}$ and $G$ represent p(NH)ppG and GTP. respectively.

(c) The same final deactivation is attained when OC-PZ $\left(H^{1}\right)$ and $R^{1}$ are used again instead of secretin $\left(H^{2}\right)$ and $R^{2}$.

\section{Acknowledgments}

This work was supported by Grant RO-IAM-17010 from the National Institutes of Health (USA) and by Grant No. 20,403 from the Belgian Medical Scientific Research Fund.

\section{References}

[1] Christophe, J. P., Conlon, T. P. and Gardner, J. D. (1976) J. Biol. Chem. 251, 4629-4634.

[2] Milutinovié, S., Schulz, L. and Rosselin, G. (1976) Biochim. Biophys. Acta 436,113-127.

[3] Christophe, J., Robberecht, P. and DeschodtLanckman, M. (1977) in: Progress in Gastroenterology (Glass, G. B. J. ed) vol. 3, pp. 241-284, Grune and Stratton, New York.

[4] Kempen, H. J. M., de Pont, J. J. H. H. M. and Bonting, S. L. (1974) Biochim. Biophys. Acta 370, 573-584.

[5] Svoboda, M., Robberecht, P., Camus, J., DeschodtLanckman, M. and Christophe, J. (1976) Eur. J. Biochem. 69, 185-193.

[6] Rodbell, M., Lin, M. C., Salomon, Y., Londos, C., Harwood, J. P., Martin, B. R., Rendel, M. and Berman, M. (1975) in: Advances in Cyclic Nucleotide Research (Drummond, G. 1., Greengard, P. and Robinson, G. A. eds) vol. 5, pp, 3-29. Raven Press, New York.

[8] Lefkowitz, R. J.and Caron, M. G. (1975) J. Biol. Chem. $250,4418-4422$.

[9] Glossmann, H. and Gips, H. (1975) NaunynSchmiedeberg's Arch. Pharmacol. 289, 77-97.

[10] Pfeuffer, T. and Helmreich, E. J. M. (1975) J. Biol. Chem. 250, 867-876.

[11] Svoboda, M., Robberecht, P., Carnus, J., DeschodtLanckman, M. and Christophe, J. (1978) Eur. J. Biochem. 83, 287-297.
[12] Schramm, M, and Rodbell, M. (1975) J. Biol. Chem. $250,2232-2237$.

[13] Spiegel, A. M., Brown, E. M., Fedak, S. A., Woodard, C. J. and Aurbach, G. D. (1976) J. Cycl, Nucl. Res. $2,47-56$.

[14] Cuatrecasas, J., Jacobs, S. and Bennett, V. (1975) Proc. Natl. Acad, Sci. USA 72, 1739-1743.

[15] Sevilla, N., Steer, M. L. and Levitzki, A. (1976) Biochemistry 15, 3493-3499.

[16] Cassel, D. and Selinger, Z. (1977) J. Cycl. Nucl. Res. $3,11-22$.

[17] Sevilla, N. and Levitzki, A. (1977) FEBS Lett. 76, $129-134$.

[18] Cassel, D. and Selinger, Z. (1976) Biochim. Biophys. Acta 452, 538-551.

[19] Cassel, D., Levkovitz, H. and Selinger, Z. (1977) J. Cycl. Nucl. Res. 3, 393-406.

[20] Salomon, Y., Londos, C. and Rodbell, M. (1974) Anal. Biochem. 58, 541-548.

[21] Lowry, O. H., Rosebrough, N. J., Farr, A. L. and Randall, R. J. (1951) J. Biol. Chem. 193, 265-275.

[22] Levitzki, A. (1977) Biochem, Biophys. Res. Commun. $74,1154-1159$.

[23] Rendell, M. S., Rodbell, M. and Berman, M. (1977) J. Biol, Chem. 252, 7909-7912.

[24] Spiegel, A. M., Downs, R. W. jr. and Aurbach, G. D. (1977) Biochem. Biophys. Res. Commun. 76, 758-764.

[25] Lad, P. M., Welton, A. F, and Rodbell, M. (1977) J. Biol. Chem. 252, 5942-5946.

[26] Deschodt-Lanckman, M., Svoboda, M., Camus, J. C. and Robberecht, P. (1977) in: Hormonal Receptors in Digestive Tract Physiology (Bonfils, S., Fromageot, P. and Rosselin, G., eds) pp. 325-326, North-Holland, Amsterdam.

[27] Jacobs, S. and Cuatrecasas, P. (1976) Biochim. Biophys. Acta 433, 482-495.

[28] Boeynaems, J. M. and Dumont, J. E. (1975) J. Cycl. Nucl. Res. 1, 123-142.

[29] Orly, J. and Schramm, M. (1976) Proc. Natl. Acad. Sci. USA $73,4410-4414$.

[30] Schramm, M., Orly, J., Eimerl, S. and Korner, M. (1977) Nature 268, 310-313.

[31] Pfeuffer, T. (1977) J. Biol. Chem. 252, 7224-7234.

[32] Tolkovsky, A. M. and Levitzki, A. (1978) Hormones and Cell Regulation 2, 89-104. 